\title{
The Role of Local Government Internal Auditor Competencies and Local Government Managerial Integrity in Improving the Performance Quality of Local Government Agencies
}

\author{
Ony Widilestariningtyas \\ Department of Accounting \\ Universitas Komputer Indonesia \\ Bandung, Indonesia \\ ony.widilestariningtyas@email.unikom.ac.id
}

\begin{abstract}
- the need for regional government will be the role of internal auditors in order to support the realization of quality local government agencies' performance is needed in managerial activities of the regional work unit (SKPD) leaders with integrity in the local government. This study examines the role of the main tasks and functions of internal auditors in the local government to improve the quality of the performance of local government agencies and examine the role of leadership integrity that functions as structural managerial in the local government to carry out daily local government operations, so as to create quality local government agencies. The research method used was the descriptive and explanatory approach. This research was carried out in the local government. The test uses Spearman's correlation rho. The unit of analysis of internal auditors within the local government inspectorate and leadership within the regional executive unit. Sample withdrawal method using purposive sampling. This study can answer the role of government internal auditors in improving the quality of performance of local government agencies and the managerial functions of leaders who have integrity in leading the regional implementing units as institutions that encourage the realization of quality agency performance.
\end{abstract}

Keywords- Internal auditors, internal auditor competence, Integrity, Performance Quality agencies.

\section{INTRODUCTION}

Competent internal auditors have sufficient expertise explicitly used to audit objectively. Reference [1] stated that integrity includes acting honestly, credibly, and consistency. Reference [2] explained that integrity must be achieved by managerial the regional work unit (SKPD), so that government performance should be translated as an evaluation activity to assess or see the successes and failures of the implementation of tasks and functions imposed on it [3]. The focus of performance-based management is the measurement of outcome, not just the measurement of inputs and outputs. Results-oriented public management is called result oriented management [4], namely a government that finances outcomes rather than inputs. Reference [5] explained partially determinant factors (input and process) have a significant influence on the quality of agency performance. Reference [6] defines that "competency is a fundamental characteristic possessed by someone who has a direct influence on, or can predict, a very good performance. Reference [7] explains that to find out the quality of service that is perceived significantly by the community lies in the ten dimensions of service quality according to what the community says, namely competence (competent), the demand for knowledge and skills both by the apparatus in providing services. Reference [8] stated that the form of ownership of self-integrity arises in the form of performance or good work. And to be able to have good performance, competence is needed, a reliable ability in the field. With the integrity of the self, competence can be more directed to produce good and quality performance. Because the previous research only explained each variable from a different unit of analysis with different methods and different approaches. The hope of this study can provide an overview of good and quality performance perspectives from the results of the work of competent internal auditors and integrated managerial leadership. This study examines the role of the main tasks and functions of internal auditors in the local government to improve the quality of the performance of local government agencies and examine the role of leadership integrity that functions as structural managerial in the local government to carry out daily local government operations, so as to create quality local government agencies.

\section{METHOD}

This research method in this study was descriptive method and explanatory method with descriptive research approach to provide a clear picture of internal auditor competency, managerial integrity, and agency performance quality. The unit of analysis is the internal auditor in the local government and the head of the regional implementing unit in the local government. The test uses Spearman's correlation rho. Sample withdrawal method using purposive sampling. 
The unit of analysis of this research is the regional work unit (SKPD). The study population was 33 SKPD units audited by 33 internal auditors Bandung Regency, West Java Province. The sampling technique used was a survey because the number of population and sample were the same as 33 units. Data collection techniques using observation, interviews, questionnaires and literature studies. The type of research data is primary data in the form of a questionnaire. This study uses descriptive analysis method with scoring analysis method to be able to interpret the results of the questionnaire.

This research variable consists of internal auditor competence, integrity, and agency performance. The indicators of each variable are as follows: internal auditor competence variables use indicators [9] : 1) knowledge, 2) expertise, 3) behavioral attitudes, and 4) continuing professional education and training; integrity variables use indicators [10] : 1) auditor honesty, 2) auditor courage, 3) auditor's wise attitude, and 4) auditor's responsibilities; quality agency performance variables using indicators: 1) specific and clear, 2) can be measured objectively both quantitative and qualitative, 3) relevant, 4) achievable, important and must be useful to show the success of input, output, benefits and impact and process, 5) must be flexible and sensitive to changes / adjustments to the implementation and results of the implementation of activities, 6) effective data / information related to the performance indicators concerned can be collected, processed, and analyzed with available costs.

In Figure 1 shows the relationship of auditor internal competence as a component in the assessment of performance quality that refers to reference [6]. And Integrity is a guideline in showing self-commitment in carrying out tasks so that it shows the best performance in referring to reference [8].

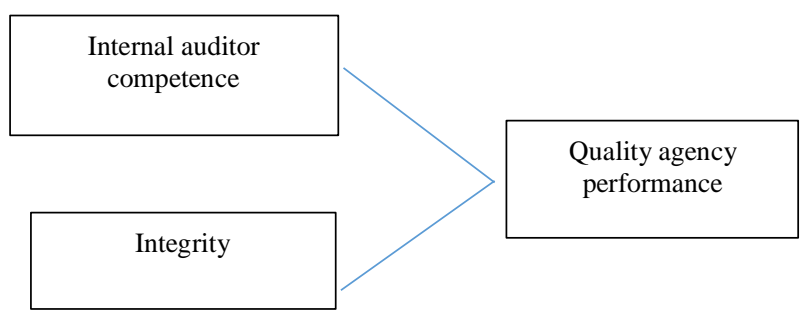

Figure 1. Research paradigm

Based on the description of previous research, this research paradigm can be described in Figure 1 demonstrate the linkages between internal auditor competency variables and integrity to the performance of quality agencies.

\section{RESULTS}

The results of this study indicate respondents' responses to each variable with the following research indicators, in table 1 shows the results of the study based on a questionnaire from respondents' responses to the head of the regional work unit (SKPD). That assesses the competence of internal auditors who have audited the SKPD business entities concerned. The Head of the SKPD assesses that the auditor's competence in the criteria of knowledge, expertise, and attitude towards carrying out his duties is good, but in the implementation of continuing professional education and training it is still considered quite good. Nevertheless, overall the competence of internal auditors is considered to be the head of the SKPD is good.

TABLE 1. INTERNAL AUDITOR COMPETENCE VARIABLES USE INDICATORS.

\begin{tabular}{|l|l|l|}
\hline NO. & \multicolumn{1}{|c|}{ INDICATORS } & VALUE INDEX \\
\hline 1. & knowledge & Good \\
\hline 2. & expertise & Good \\
\hline 3. & behavioral attitudes & Good \\
\hline 4. & continuing professional education and training & Good Enough \\
\hline \multicolumn{2}{|l|}{ internal auditor competence variables } & Good \\
\hline
\end{tabular}

Based on Table 1 shows the competence of internal auditors is considered good if the four assessment components are fulfilled by qualifying the good index.

Table 2 shows the results of respondents 'responses, namely the Head of the regional work unit (SKPD). responds to the integrity of internal auditors in carrying out their duties with criteria of honesty, wise attitude and auditor responsibilities are good, but for auditors' courage is still considered quite good. However, overall the integration of internal auditors is considered to be the head of the SKPD is good.

TABLE 2. INTEGRITY VARIABLES USE INDICATORS.

\begin{tabular}{|l|l|c|}
\hline NO. & \multicolumn{1}{|c|}{ INDICATORS } & VALUE INDEX \\
\hline 1. & auditor honesty & Good \\
\hline 2. & auditor courage & Good Enough \\
\hline 3. & auditor's wise attitude & Good \\
\hline 4. & auditor's responsibilities & Good \\
\hline \multicolumn{2}{|l|}{ integrity variables } & Good \\
\hline
\end{tabular}

Based on Table 2 shows the integrity of internal auditors is considered good if an internal auditor is able to show identity in the assignment with the four qualifications above is considered good.

Table 3 shows respondents' responses to the performance of qualified internal auditors in carrying out their duties with the following achievement criteria: specific and clear assignments, can be measured objectively both quantitative and qualitative, relevant, and effective data / information related to the performance indicators concerned can be collected, processed, and analyzed with available costs assessed by the head of the regional work unit (SKPD). Whereas according to the Head of SKPD the performance criteria can be achieved, it is important and must be useful to show the success of input, output, results of benefits and impacts and processes, and the criteria must be flexible and sensitive to changes / adjustments to implementation and the results of the implementation of activities are still considered quite good. Overall, the Head of SKPD's 
assessment of the quality of auditor performance is good. As can be seen in table 3 .

TABLE. 3 QUALITY AGENCY PERFORMANCE VARIABLES USING INDICATORS.

\begin{tabular}{|l|l|c|}
\hline NO. & \multicolumn{1}{|c|}{ INDICATORS } & VALUE INDEX \\
\hline 1. & specific and clear & Good \\
\hline 2. & $\begin{array}{l}\text { can be measured objectively both } \\
\text { quantitative and qualitative }\end{array}$ & Good \\
\hline 3. & relevant & Good Enough \\
\hline 4. & $\begin{array}{l}\text { achievable, important and must be useful to } \\
\text { show the success of input, output, benefits } \\
\text { and impact and process, }\end{array}$ & $\begin{array}{l}\text { Good Enough } \\
\text { adjustments to the implementation and } \\
\text { results of the implementation of activities }\end{array}$ \\
\hline 5. & $\begin{array}{l}\text { effective data / information related to the } \\
\text { performance indicators concerned can be } \\
\text { collected, processed, and analyzed with } \\
\text { available costs }\end{array}$ & Good \\
\hline 6.
\end{tabular}

Based on Table 3 shows the quality of the auditor's performance in assessing SKPD entities examined is a separate observation from each SKPD head. In this study shows good results based on the six qualifications of auditor performance appraisal.

The results of this study answer the phenomenon 1) that the internal auditor in carrying out the audit assignment is quite good. 2) The implementation of programs and activities in the regional implementation unit has been carried out quite well. 3) The results of the performance of the regional technical implementation unit are quite good.

\section{DISCUSSION}

This view is supported by auditor internal (AI) [12] who suggest that the staffing of internal audit departments and the management of its staff is vital to the effective operation of IA, and that unless they possess the necessary competencies the power of internal auditors may be diminished.

Competent internal auditors are qualified according to BPKP provisions, namely 1) good knowledge, 2) adequate skills / expertise, 3) good behavior, and 4) continuous education and professional training that consistently have good enough value. So that an internal auditor can be judged to have good competence.

Based on references [13], the results of research on integrity affect the performance of agencies. Internal auditors have good integrity with the attainment of the following qualifications: 1) good auditor honesty, 2) auditors who have good enough courage, 3) good auditor sensibility and 4) adequate auditor responsibilities. So that an internal auditor is expected to provide a good assessment in accordance with the integrity capabilities that must be owned. Besides that, integrity principles [11] cannot be ignored, namely: 1) understanding and recognizing behavior according to the code of ethics, 2) taking actions that are consistent with their values and key values, 3) acting on values even though it is difficult to do so, and 4) acting on values even though there is a risk or substantial costs.
This study shows that the performance of good quality institutions is assessed by the following performance achievements [9] : 1) agency performance is considered good if it shows specific and clear performance so that it can be understood and there is no possibility of misinterpretation, 2) Can be measured objectively both quantitative and Adequate qualitative, namely two or more measuring performance indicators have the same conclusions, 3) Relevant has been assessed as good, performance indicators must deal with relevant objective aspects, 4) Can be achieved, important, and must be useful to show the success of input, output, the results, benefits and impacts and processes are still considered sufficient, 5) Must be flexible and sensitive to changes / adjustments to the implementation and results of the implementation of activities are still considered quite good, 6) Effective data / information relating to the performance indicators concerned can be collected, processed, and analyzed with fees available is good. Agency performance can also be assessed with the following sizes [9]: 1) Consistency. Various definitions used to formulate performance indicators must be consistent, both between time periods and between organizational units, 2) Comparability. Performance indicators must have appropriate comparability, 3) Clarity. Performance indicators must be simple, clearly defined and easily understood, 4) Controllability. Performance measurement of a public manager must be based on areas that can be controlled, 5) Contingency. Formulation of performance indicators is not a variable that is independent of the internal and external environment. The organizational structure, management style, uncertainty and complexity of the external environment must be considered in the formulation of performance indicators, 6) Comprehensiveness. Performance indicators must reflect all aspects of behavior that are important enough for managerial decision making, 7) Boundedness. Performance indicators must focus on the main factors that are the success of the organization, 8) Relevance. Various applications require specific indicators so that they are relevant for certain conditions and needs, 9) Feasibility. The targets used as the basis for formulating performance indicators must be realistic and achievable expectations.

The results of this study explain that internal auditors in carrying out audit assignments have fulfilled the competencies set by BPKP. While the entity examined examines the work results of the program and activities that have been carried out in the fiscal year. The assessment of the results of the performance of a qualified local government gets an assessment based on public accountability.

\section{CONCLUSION}

Good and quality performance results are generated from the results of the examination of competent internal auditors and the results of the implementation of programs and activities of the regional implementing units in carrying out the planning of the head of service as a result of managerial leadership with good integrity. The need for competent and integrity internal auditors greatly supports the achievement of quality local government agencies. So that the BPKP as a government agency that always 
oversees government activities in carrying out programs and activities in accordance with the commitment of the local government to the community.

\section{ACKNOWLEDGMENT}

Thank you to the Chancellor and the leader of UNIKOM for giving the opportunity for the publication of our scientific work.

\section{REFERENCES}

[1] Sri Lastini,Hexana.2005, "Tinjauan Terhadap Kompetensi dan Independensi Akuntan Publik : Refleksi Atas Skandal Keuangan".Media Riset Akuntansi Auditing dan Informasi, Vol.5 No. 1 April 2005.

[2] John R. Schermerhorn, Jr., James Hunt, Richard N. Osborn, and Uhl. Bien, Organizational Behavior, Twelfth Edition. (New Jersey: John Wiley \& Son, Inc., 2012).

[3] Nugroho, 2000. Keperawatan Gerontik Edisi Kedua, Jakarta: EGC

[4] Mahmudi. (2010). Manajemen Kinerja Sektor Publik. Yogyakarta: Akademi Manajemen Perusahaan YKPN.

[5] Geraldino A. Sayd,dkk, "Faktor-Faktor yang Mempengaruhi Kualitas Kinerja Kantor Pertanahan Rote Ndao", Jurnal Ilmu Sosial dan Ilmu Politik Volume 19, Nomor 3, Maret 2016 (264-274) ISSN 1410-4946.

[6] Rivai, Veitzhal, et. al, 2011. Corporate Performance Management dari Teori Ke Praktik Solusi Tepat dan Mudah Memajukan Perusahaan dengan Menilai Kinerja Perusahaan,Bogor: Ghalia Indonesia.

[7] Sedarmayanti, 2013. Manajemmen Sumber Daya Manusia Reformasi Birokrasi dan Manajemen Pegawai Negeri Sipil, Bandung:PT. Refika Aditama.

[8] Gea A. A. (2014). INTEGRITAS PERSONAL DAN KEPEMIMPINAN ETIS. Humaniora, 5 (2), 950-959.

[9] BPKP, (2010), Peraturan Kepala Badan Pengawas Keuangan \& Pembangunan Nomor : PER-211/K/JF/2010 tentang Standar Kompetensi Auditor, Jakarta.

[10] Sukriah, Ika et al. (2009). Pengaruh Pengalaman Kerja, Independensi, Objektivitas, Integritas, dan Kompetensi terhadap Kualitas Hasil Pemeriksaan. Jurnal. Simposium Nasional Akuntansi XII.

[11] Sukrisno, Agoes, (2004), Pemeriksaan Akuntansi, Jakarta : Penerbit Salemba Empat.

[12] Al-Twaijry, A. B. (2003). The development of internal audit in Saudi Arabia: an institutional theory perspective. Critical Perspectives on Accounting, 507-31.

[13] Muslim Djalil, Mirna Indriani, The Influence of Leadership Style, Integrity and Organizational Commitment on the Performance of State Development Audit Agency (BPKP) at BPKP Representative Office of Aceh Province, Indonesia. Available from: https://www.researchgate.net/publication/312589428 The Influenc e_of_Leadership_Style_Integrity_and_Organizational_Commitmen t on the Performance of State Development Audit Agency BP KP at BPKP Representative Office of Aceh Province Indonesi a [accessed Oct 16 2018]. 